\title{
Oxidative Stress Status in COVID-19 Patients Hospitalized in Intensive Care Unit for Severe Pneumonia. A Pilot Study
}

\author{
Joël Pincemail ${ }^{1, *}$, Etienne Cavalier ${ }^{1}$, Corinne Charlier ${ }^{2}$, Jean-Paul Cheramy-Bien ${ }^{3}$, Eric Brevers ${ }^{1}$, \\ Audrey Courtois ${ }^{3}\left(\mathbb{D}\right.$, Marjorie Fadeur ${ }^{4}$, Smail Meziane ${ }^{5}$, Caroline Le Goff ${ }^{1}$, Benoît Misset ${ }^{6}$, Adelin Albert ${ }^{7}$, \\ Jean-Olivier Defraigne ${ }^{3}$ and Anne-Françoise Rousseau ${ }^{6}$ (D)
}

Citation: Pincemail, J.; Cavalier, E. Charlier, C.; Cheramy-Bien, J.-P.; Brevers, E.; Courtois, A.; Fadeur, M.; Meziane, S.; Goff, C.L.; Misset, B.; et al. Oxidative Stress Status in COVID-19 Patients Hospitalized in Intensive Care Unit for Severe Pneumonia. A Pilot Study. Antioxidants 2021, 10, 257. https://doi.org/10.3390/ antiox10020257

Academic Editors: Javier Diaz-Castro and Jorge Moreno-Fernandez

Received: 4 January 2021

Accepted: 2 February 2021

Published: 7 February 2021

Publisher's Note: MDPI stays neutral with regard to jurisdictional claims in published maps and institutional affiliations.

Copyright: (c) 2021 by the authors. Licensee MDPI, Basel, Switzerland. This article is an open access article distributed under the terms and conditions of the Creative Commons Attribution (CC BY) license (https:/ / creativecommons.org/licenses/by/ $4.0 /)$.
1 Clinical Chemistry, CHU of Liège, Sart Tilman, 4000 Liège, Belgium; etienne.cavalier@chuliege.be (E.C.); e.brevers@chu.ulg.ac.be (E.B.); c.legoff@chu.ulg.ac.be (C.L.G.)

2 Toxicology Department, CHU of Liège, Sart Tilman, 4000 Liège, Belgium; c.charlier@chuliege.be

3 Department of Cardiovascular Surgery, CHU of Liège, Sart Tilman, 4000 Liège, Belgium; JP.Cheramy@chuliege.be (J.-P.C.-B.); a.courtois@chuliege.be (A.C.); jo.defraigne@chuliege.be (J.-O.D.)

4 Service of Diabetology, Nutrition and Metabolic Diseases, CHU of Liège, Sart Tilman, 4000 Liège, Belgium; marjorie.fadeur@chuliege.be

5 Institut Européen des Antioxydants, 54000 Nancy, France; smeziane@ie-antioxydants.com

6 Intensive Care Department, CHU of Liège, Sart Tilman, 4000 Liège, Belgium;

benoit.misset@chuliege.be (B.M.); afrousseau@chuliege.be (A.-F.R.)

7 Biostatistics and Medico-economic Information Department, CHU of Liège, Sart Tilman, 4000 Liège, Belgium; aalbert@uliege.be

* Correspondence: j.pincemail@chuliege.be

Abstract: Background: A key role of oxidative stress has been highlighted in the pathogenesis of COVID-19. However, little has been said about oxidative stress status (OSS) of COVID-19 patients hospitalized in intensive care unit (ICU). Material and Methods: Biomarkers of the systemic OSS included antioxidants ( 9 assays), trace elements (3 assays), inflammation markers (4 assays) and oxidative damage to lipids ( 3 assays). Results: Blood samples were drawn after 9 (7-11) and 41 (39-43) days of ICU stay, respectively in 3 and 6 patients. Vitamin C, thiol proteins, reduced glutathione, $\gamma$-tocopherol, $\beta$-carotene and PAOT $^{\circledR}$ score were significantly decreased compared to laboratory reference values. Selenium concentration was at the limit of the lower reference value. By contrast, the copper/zinc ratio (as a source of oxidative stress) was higher than reference values in $55 \%$ of patients while copper was significantly correlated with lipid peroxides $(\mathrm{r}=0.95, p<0.001)$. Inflammatory biomarkers (C-reactive protein and myeloperoxidase) were significantly increased when compared to normals. Conclusions: The systemic OSS was strongly altered in critically ill COVID-19 patients as evidenced by increased lipid peroxidation but also by deficits in some antioxidants (vitamin C, glutathione, thiol proteins) and trace elements (selenium).

Keywords: COVID-19; oxidative stress; critical care; vitamin C; lipid peroxides

\section{Introduction}

Severe acute respiratory syndrome coronavirus 2 (SARS-CoV-2) was responsible for Coronavirus disease 2019 (COVID-19), the first cases having been reported in Wuhan, China, in December 2019 [1]. Due to fast transmission and pathogenicity, the coronavirus has spread across all countries, provoking a pandemic [2]. COVID-19 is characterized by aberrant host immune response, leading to excessive inflammatory responses (or cytokine storm) — as evidenced by high blood levels of cytokines, chemokines and C-reactive protein-and is associated with severe damage to the respiratory system and multi-organ failure, contributing to fatal outcomes of infected patients [3-5]. Post-mortem analysis of COVID-19 lungs showed infiltration of inflammatory mononuclear cells and macrophages in the air spaces, which may induce diffuse remodeling of the alveolar wall [6]. 
In a large number of pathologies, inflammation is known to be closely related to oxidative stress, one process being easily induced by the other [7-9]. Oxidative stress (OS) is defined as an imbalance between toxic reactive oxygen species (ROS) and antioxidants in favor of oxidants, leading to a disruption of redox signaling and/or irreversible oxidative damage to lipids, deoxyribonucleic acid (DNA) or proteins [10]. Oxidative damages are involved in the development of different pathologies including cancer, cardiovascular, neurodegenerative and lung diseases [11]. Besides inflammation, other pathophysiological mechanisms in relationship with increased OS have been advocated to explain the pathogenesis of COVID-19 [12]: inhibition of angiotensin converting enzyme 2 (ACE-2) activity [13-16], denaturation of hemoglobin leading to iron metabolism dysregulation with release of toxic free iron ion [17-21], disseminated intravascular coagulation due to hypoxia [12] and endothelial dysfunction [22-26].

Despite recent papers highlighting the key role of oxidative stress and inflammation duo in the development of COVID-19 [12,27,28], little information is available about the systemic oxidative stress status (OSS) of COVID-19 patients hospitalized in intensive care unit (ICU) for severe pneumonia. The present study aimed to specifically identify blood biomarkers of OS including antioxidants, trace elements, and oxidative damages to lipids in such COVID-19 patients and to analyze their relationship with inflammation as a major source of ROS production.

\section{Material and Methods}

This study was conducted during the first wave of the COVID-19 pandemic in May 2020 in the 50-bed Intensive Care Unit (ICU) of the University Hospital of Liège in Belgium. Due to the particular context of the pandemic, we received first a written agreement from the President of local Ethical Committee on 29 April 2020. The study protocol was then formally approved under national reference B707202000035, Local reference 2020-201, on 5 June 2020. All legal representatives of the patients were instructed on the study objectives and signed informed consent.

The study was conducted on a convenience sample of critically ill adult patients hospitalized for severe COVID-19 pneumonia. Patients were excluded if they were weaned from mechanical ventilation and if they were on continuous veno-venous hemofiltration $(\mathrm{CVVH})$ during the 7 days before blood sampling. In total, nine patients were included.

All the patients received medical nutrition following the local nutritional practices. According to the nutritional guidelines that were available at the time of the study, weightbased formulas were used to estimate energy and protein targets (Table 1). Enteral nutrition was administered continuously using a volumetric pump. Gastric residual volume was monitored every $6 \mathrm{~h}$ : in case of volume $\geq 250 \mathrm{~mL}$, feeding rate was reduced and prokinetics (metoclopramide or erythromycin) were considered at the intensivist's discretion. The different industrial enteral solutions were: Nutrison Protein Plus, Nutrison Energy Multi Fibre, (Nutricia ${ }^{\circledR}$, Brussels, Belgium) and Peptamen AF (Nestlé Health Science ${ }^{\circledR}$, Brussels, Belgium). In case of insufficient or contraindicated enteral nutrition, respectively supplemental or total parenteral nutrition was initiated using a ternary mixture (Smofkabiven, Fresenius Kabi ${ }^{\circledR}$, Schelle, Belgium). Parenteral nutrition was administered continuously via a central venous line, using a volumetric pump. Patients on parenteral nutrition or continuous veno-venous hemofiltration were supplemented with micronutrients (Addaven ${ }^{\circledR}$, Soluvit ${ }^{\circledR}$ Novum, Vitalipid ${ }^{\circledR}$ Novum Adult (Frésénius Kabi ${ }^{\circledR}$, Schelle, Belgium)).

Demographic data (age, sex, weight, height, body mass index (BMI), medical history, severity scores, organ support duration, route of nutrition, length of stay (LOS), survival) were collected for all patients from the electronic medical record. 
Table 1. Nutrition calculations. y: years; ${ }^{*}$ BMI: body mass index; CVVH: continuous veno-venous hemofiltration; ** IBW: ideal body weight.

\begin{tabular}{|c|c|}
\hline \multicolumn{2}{|c|}{ Body Weight Considered for Nutritional Calculations } \\
\hline $\begin{array}{l}\text { Eutrophic patients: } \\
* \text { < 75y: BMI 18.5-25 kg/m² } \\
* \geq 75 y: \text { BMI } 23-28 \mathrm{~kg} / \mathrm{m}^{2}\end{array}$ & $\begin{array}{l}\text { Actual weight: measured in hospital or obtained } \\
\text { from patient's recent medical history }\end{array}$ \\
\hline Underweight patients & $\begin{array}{c}* \text { IBW }=\text { expected weight for } \\
* \mathrm{BMI}=18.5 \mathrm{~kg} / \mathrm{m}^{2} \text { if age }<75 \mathrm{y} \\
* \mathrm{BMI}=23 \mathrm{~kg} / \mathrm{m}^{2} \text { if age } \geq 75 \mathrm{y}\end{array}$ \\
\hline Overweight patients & $\begin{aligned} \text { IBW } & =\text { expected weight for } \\
* \mathrm{BMI} & =25 \mathrm{~kg} / \mathrm{m}^{2} \text { if age }<75 \mathrm{y} \\
* \mathrm{BMI} & =28 \mathrm{~kg} / \mathrm{m}^{2} \text { if age } \geq 75 \mathrm{y}\end{aligned}$ \\
\hline $\begin{array}{c}\text { Obese patients: } \\
*<75 \mathrm{y}: \mathrm{BMI} \geq 30 \mathrm{~kg} / \mathrm{m}^{2} \\
* \geq 75 \mathrm{y}: \mathrm{BMI} \geq 30 \mathrm{~kg} / \mathrm{m}^{2}\end{array}$ & $\begin{array}{c}\text { Adjusted IBW }= \\
* * \text { IBW }+0.25 \times(\text { actual weight }- \text { IBW })\end{array}$ \\
\hline \multicolumn{2}{|c|}{ Nutritional targets } \\
\hline Eutrophic, underweight and overweight patients & $\begin{array}{c}\text { Energy: } 25 \mathrm{kcal} / \mathrm{kg} / \mathrm{d} \\
\text { Protein: } 1.2 \mathrm{~g} / \mathrm{kg} / \mathrm{d}(1.7 \mathrm{~g} / \mathrm{kg} / \mathrm{d} \text { if } \mathrm{CVVH})\end{array}$ \\
\hline Obese patients & $\begin{array}{l}\text { Energy: } 20 \mathrm{kcal} / \mathrm{kg} / \mathrm{d} \\
\text { Protein: } 2 \mathrm{~g} / \mathrm{kg} / \mathrm{d}\end{array}$ \\
\hline
\end{tabular}

Blood samples drawn from a venous central line on tubes containing EDTA and citrate were immediately centrifuged at $3000 \times g$ during $10 \mathrm{~min}$. Serum gel was allowed to clot during $30 \mathrm{~min}$ before being centrifuged. Plasma and sera samples were then frozen at $-80{ }^{\circ} \mathrm{C}$ until analysis of OS biomarkers. Blood determination of antioxidants, respectively vitamins $C$ and $E$ ( $\gamma$ - and $\alpha$-tocopherols), vitamin $E$ standardized to cholesterol (Vit $\mathrm{E} /$ cholesterol), $\beta$-carotene, glutathione (GSH), thiol proteins (PSH), glutathione peroxidase $(\mathrm{GPx})$, trace elements (selenium (Se), copper $(\mathrm{Cu})$, zinc $(\mathrm{Zn})$, copper / zinc ratio), biomarkers of oxidative damages to lipids (lipid peroxides (ROOH), oxidized LDL (ox-LDL), and antibodies IgG against oxidized LDL (Ab-ox-LDL) has been described in detail $[29,30]$. C-reactive protein (CRP) concentration was determined on a COBAS ${ }^{\circledR} 8000$ analyzer (Roche Diagnostics, Machelen, Belgium). Myeloperoxidase (MPO) was assessed using MPO ELISA kit (Immun Diagnostik, Bensheim, Germany). Cholesterol was measured using an enzymatic method with cholesterol oxidase on Abbott Alinity C (Abbott, Chicago, IL, USA). Albumin was assessed by spectrophotometry using Alinity C kit (Abbott, Chicago, IL, USA). White blood cells and neutrophils were determined by flow fluorocytometry on Sysmex-SN device (Ontario, Canada). The total antioxidant capacity (TAC) of plasma was evaluated by using the PAOT ${ }^{\circledR}$ (Pouvoir AntiOxydant Total, Institut Européen des Antioxydants, Nancy, France) score as previously described [31]. Briefly, the measurement was carried out in a reaction medium $(1 \mathrm{~mL}$ physiological solution at $\mathrm{pH}$ ranging from 6.7 to 7.2 , temperature $24-27^{\circ} \mathrm{C}$ ) containing a molecule in a free radical state called mediator (M•). Two microelectrodes, one being the working electrode and the second one the reference electrode, were then immersed in the medium. After addition of $20 \mu \mathrm{L}$ of plasma, the PAOT activity was estimated by registering electrochemical potential modifications in the reaction medium. Blood concentrations of all OS biomarkers were compared to the reference values applicable in the central laboratory of the CHU of Liège [29,30].

Patients were divided in two groups according to the ICU stay duration. Patients with an ICU stay $\leq 10$ days (short stayers, $\mathrm{N}=3$ patients) or $>10$ days (long stayers, $\mathrm{N}=6$ patients) before blood sampling were arbitrarily defined as short or long stayers, respectively.

\section{Statistical Analysis}

Quantitative data were expressed as median and range while numbers and percent were used for categorical findings. To compare the distribution of biological parameters of COVID-19 patients with the laboratory reference intervals, we used the sign test based on the binomial distribution. Specifically, according to the sign test, when all COVID-19 
patient values fell below (or above) the middle of the reference interval, we concluded that the biological test was significantly lowered (or increased) in COVID-19 patients ( $p=0.004)$ and likewise for eight COVID-19 patients ( $p=0.040)$; otherwise, COVID-19 patients were not statistically different from presumably healthy subjects. Comparison of OSS between short and long stayers was made using the nonparametric Mann-Whitney U test. Results were considered significant at the $5 \%$ critical level $(p<0.05)$. The Spearman correlation coefficient was calculated to measure the association between biological parameters. A $p$-value $<0.05$ was considered as statistically significant.

\section{Results}

The characteristics of the nine study patients are described in Table 2. Most of the patients were overweight and/or presented pathologies such as type 2 diabetes $(64 \%)$ or arterial hypertension $(66 \%)$.

Table 2. Demographic data of COVID-19 patients ( $\mathrm{N}=9$ ). BMI: body mass index; LOS: length of stay; SAPS II: simplified acute physiology score II; ICU: intensive care unit. Data are expressed as median (P25-P75) or number (\%).

\begin{tabular}{cc}
\hline Variable & Summary Statistics \\
\hline Age $(\mathrm{y})$ & $64(53-71)$ \\
Sex ratio $(\mathrm{M} / \mathrm{F})$ & $8 / 1$ \\
Weight $(\mathrm{kg})$ & $90(81-102)$ \\
Height $(\mathrm{cm})$ & $173(169-181)$ \\
BMI $(\mathrm{kg} / \mathrm{m} 2)$ & $29.4(28.4-32.3)$ \\
Active smoking, $\mathrm{n}(\%)$ & $1(11)$ \\
Active alcoholism, $\mathrm{n}(\%)$ & $1(11)$ \\
Pre-existing medical conditions: & $6(66)$ \\
- Type 2 diabetes, n (\%) & $6(66)$ \\
- Arterial hypertension, $\mathrm{n}(\%)$ & $1(11)$ \\
- Gastric sleeve surgery & $33(25-45)$ \\
SAPS II & $54(42-65.5)$ \\
ICU LOS (d) & $63(49-91)$ \\
Hospital LOS (d) & $38(20-49)$ \\
CVVH during ICU stay, $\mathrm{n}(\%)$ & $1(11)$ \\
Enteral nutrition during ICU stay, $\mathrm{n}(\%)$ & $9(100)$ \\
Supplemental parenteral nutrition during ICU & $3(33)$ \\
stay, n (\%) & \\
\hline
\end{tabular}

All the patients were on enteral feeding and one patient received supplemental parenteral nutrition during the 7 days before blood sampling. During the entire ICU stay before blood sampling, $3 / 9$ patients received temporary supplemental parenteral nutrition in addition to insufficient enteral nutrition, and 3/9 patients had been temporarily on $\mathrm{CVVH}$. These patients received an intravenous supplementation in vitamins and trace elements. Mean daily macro- and micronutrients intakes from ICU admission to blood sampling are described in Table 3.

As shown in Table 4, the median concentration of vitamin C, $\gamma$-tocopherol, $\beta$-carotene, $\mathrm{PSH}, \mathrm{GSH}$ and $\mathrm{PAOT}^{\circledR}$ score was statistically lower than the reference interval when considering all patients. By contrast, those of GPx, MPO, neutrophils count and CRP was significantly higher than the standards. Figures S1-S3 (see Supplementary Material) show all the individual OS biomarkers values when compared to the reference interval. Vitamin C, PSH and GSH concentrations were below the lower normal value (LNV) in almost all patients. By contrast, elevated levels in GPX ROOH, copper/zinc ratio and CRP being higher than the upper normal value were found in a large majority of patients. 
Table 3. Daily nutritional intakes in vitamins, trace elements and lipids in COVID-19 patients $(\mathrm{N}=9)$ hospitalized in ICU. Data are expressed as median (P25-P75).

\begin{tabular}{cc}
\hline Variable & Summary Statistics \\
\hline $\mathrm{Cu}(\mathrm{mg} /$ day) & $1.4(1-1.8)$ \\
$\mathrm{Zn}(\mathrm{mg} /$ day) & $12.7(8.6-15.7)$ \\
$\mathrm{Se}(\mu \mathrm{g} /$ day) & $72.3(46.8-79.9)$ \\
Vitamin C (mg/day) & $124.2(94.6-172.1)$ \\
Vitamin E (mg/day) & $17(12.6-21.5)$ \\
Vitamin A ( $\mu$ g/day) & $1012(712.8-1182)$ \\
Lipids (g/day) & $42.7(27.8-54.2)$ \\
Energy (kcal/day) & $1263(899.8-1389)$ \\
Proteins (g/day) & $65.2(47.6-77.7)$ \\
\hline
\end{tabular}

Table 4. Statistical comparison of OS biomarkers in all COVID-19 patients $(\mathrm{N}=9)$ with their reference interval using the sign test based on the binomial distribution (see statistical analysis). k: number of COVID-19 values below * or above ${ }^{* *}$ the middle of reference interval.

\begin{tabular}{|c|c|c|c|c|}
\hline Variable & Reference Interval & Median (Range) & $\mathbf{k}$ & $p$ Value \\
\hline \multicolumn{5}{|l|}{ Antioxidants } \\
\hline vitamin $C(\mu \mathrm{g} / \mathrm{mL})$ & $6.21-15.18$ & $3.91(3.06-6.14)$ & 9 * & 0.004 \\
\hline vitamin $\mathrm{E}$ as $\alpha$-tocopherol $(\mu \mathrm{g} / \mathrm{mL})$ & $8.60-19.24$ & $17.90(13.3-21.1)$ & $3 *$ & 1 \\
\hline vitamin $\mathrm{E} /$ cholesterol $(\mu \mathrm{g} / \mathrm{g})$ & $4.4-7.0$ & $10.92(9.14-13.16)$ & 0 * & 1 \\
\hline$\alpha$-tocopherol $(\mu \mathrm{g} / \mathrm{mL})$ & $0.39-2.42$ & $0.84(0.57-1.28)$ & $8 *$ & 0.040 \\
\hline$\beta$-carotene $(\mathrm{mg} / \mathrm{L})$ & $0.06-0.68$ & $0.14(0.11-0.28)$ & $9 *$ & 0.004 \\
\hline thiol proteins $(\mu \mathrm{M})$ & $314-516$ & $250(204-258)$ & $9 *$ & 0.004 \\
\hline glutathione $(\mu \mathrm{M})$ & $717-1110$ & $629(508-697)$ & $8 *$ & 0.040 \\
\hline oxidized glutathione $(\mu \mathrm{M})$ & 0.96-10 & $<0.96$ & $0 * *$ & 1 \\
\hline PAOT $^{\circledR}$ score $(\mathrm{U} / \mathrm{L})$ & $1.46-36.74$ & $10.52(6.63-10.77)$ & $9 *$ & 0.004 \\
\hline glutathione peroxidase (UI/g Hb) & $20-56$ & 69.55 (61.90-78.27) & $9 * *$ & 0.004 \\
\hline albumin $(\mathrm{g} / \mathrm{l})$ & $32-46$ & $28(27.5-33.0)$ & $8 *$ & 0.040 \\
\hline \multicolumn{5}{|l|}{ Trace elements } \\
\hline copper $(\mathrm{mg} / \mathrm{mL})$ & $0.70-1.10$ & $1.16(0.66-1.47)$ & $5 * *$ & 1 \\
\hline $\operatorname{zinc}(\mathrm{mg} / \mathrm{mL})$ & $0.70-1.20$ & $0.84(0.81-1.09)$ & $5 *$ & 1 \\
\hline selenium $(\mu \mathrm{g} / \mathrm{L})$ & $73-110$ & $74(59-103)$ & $5 *$ & 1 \\
\hline \multicolumn{5}{|l|}{ Biomarkers of lipid peroxidation } \\
\hline $\mathrm{ROOH}(\mu \mathrm{M})$ & $0-432$ & $674(181-1415)$ & $6^{* *}$ & 0.50 \\
\hline ox-LDL (ng/mL) & $28-70$ & $50(36-70)$ & $5 * *$ & 1 \\
\hline Ab-ox-LDL (IU/L) & $200-600$ & $306(64-1200)$ & $4^{*}$ & 1 \\
\hline \multicolumn{5}{|l|}{ Sources of ROS production } \\
\hline copper/zinc ratio & $1.00-1.17$ & $1.55(0.79-1.69)$ & $5 * *$ & 1 \\
\hline white blood cells $\left(10^{3} / \mathrm{mm}^{3}\right)$ & $4.60-10.10$ & $8.42(7.07-13.03)$ & $6 * *$ & 0.50 \\
\hline neutrophils (\%) & $42-71$ & $75.6(60.8-86.3)$ & $8^{* *}$ & 0.04 \\
\hline myeloperoxidase (ng/mL) & $27-72$ & $88(60-191)$ & $8 * *$ & 0.04 \\
\hline C-reactive protein $(\mathrm{mg} / \mathrm{L})$ & $0-5$ & $32.8(9.6-59.8)$ & $8 * *$ & 0.04 \\
\hline
\end{tabular}

Table 5 displays the main significant correlations observed between OS biomarkers. Copper correlated positively with $\mathrm{ROOH}, \mathrm{Cu} / \mathrm{Zn}$ ratio and CRP but negatively with $\gamma$ tocopherol. $\mathrm{Cu} / \mathrm{Zn}$ ratio tended to positively correlate with $\mathrm{ROOH}$ and similarly for $\mathrm{Cu}$ and CRP. By contrast, $\gamma$-tocopherol tended to correlate negatively with ROOH, ox-LDL and CRP. MPO negatively correlated with albumin and, to a lesser extent, with PSH. No correlation was found between PSH and albumin (data not shown).

As blood samples were taken after different times in the ICU, we investigated if differences could occur in OS biomarkers concentration between short and long stayers (Table S1, see Supplementary Material). Only a significant increase in vitamin C, $\beta$-carotene and selenium was observed in long stayers when compared to short stayers. Nevertheless, the median value of both antioxidants always remained below the INV. By contrast, those of selenium has changed from $51(28-67) \mu \mathrm{g} / \mathrm{L}$ in short stayers to 97.5 (73-105) $\mu \mathrm{g} / \mathrm{L}$ in long stayers, this last value being in the reference interval. GSH concentration decreased in a non-significant way from $794 \mu \mathrm{M}$ in short stayers to $598 \mu \mathrm{M}$ in long stayers, a value 
largely below the INV. As shown in Table S2 (see Supplementary Material), abnormal values in vitamin C, PSH, GSH, GPx, copper/zinc ratio, $\mathrm{ROOH}$, neutrophils and CRP were frequent $(\geq 50 \%)$ in both groups. Low selenium levels were mostly observed in short stayers (Figure S2, see Supplementary Material).

Table 5. Correlation between some OS biomarkers as observed in COVID-19 patients. ROOH: lipid peroxides, CRP: C-reactive protein, MPO: myeloperoxidase, $\mathrm{PSH}$ : thiol proteins, $\mathrm{Cu}$ : copper, Zn: zinc.

\begin{tabular}{cccc}
\hline \multicolumn{2}{c}{ Association } & Correlation & $p$-Value \\
\hline $\mathrm{Cu}$ & $\mathrm{ROOH}$ & 0.95 & $<0.001$ \\
$\mathrm{Cu} / \mathrm{Zn}$ & $\mathrm{CRP}$ & 0.82 & 0.007 \\
$\mathrm{PAOT}^{\circledR}$ score & Vitamin E/cholesterol & 0.82 & 0.007 \\
albumin & $\mathrm{MPO}$ & -0.75 & 0.020 \\
$\mathrm{Cu}$ & $\gamma$-tocopherol & -0.75 & 0.020 \\
$\mathrm{GSH}$ & $\mathrm{PSH}$ & 0.73 & 0.026 \\
$\mathrm{Cu}$ & $\mathrm{Cu} / \mathrm{Zn}$ & 0.72 & 0.030 \\
$\gamma$-tocopherol & $\mathrm{ROOH}$ & -0.63 & 0.067 \\
$\mathrm{PAOT}^{\circledR}$ score & $\mathrm{Zn}$ & 0.63 & 0.067 \\
$\mathrm{CRP}$ & $\mathrm{Vitamin} \mathrm{E}$ & -0.61 & 0.081 \\
$\mathrm{MPO}$ & $\mathrm{PSH}$ & -0.61 & 0.081 \\
$\mathrm{Cu} / \mathrm{Zn}$ & $\mathrm{ROOH}$ & 0.58 & 0.099 \\
\hline
\end{tabular}

\section{Discussion}

To the best of our knowledge, this is the first report showing a deep alteration of systemic OSS using an analysis of a large number of biomarkers in COVID-19 patients hospitalized for severe pneumonia. Of interest to note is that results were homogenous despite a different timing (short and long stayers) in the blood collection.

\subsection{Antioxidant Analysis}

An important collapse in antioxidant defenses was detected in the COVID-19 patients as evidenced by levels of vitamin C, GSH, PSH, $\gamma$-tocopherol and $\beta$-carotene that were largely below the reference interval.

When considering all the nine COVID-19 patients, their median value in vitamin C corresponds to the definition of a hypovitaminosis C [32]. Despite a significant increase when compared to short stayers, vitamin $C$ level in long stayers remained below the inferior normal value. In a recent paper, Chiscano-Camón et al. [33] reported that undetectable vitamin C levels were observed in $94.4 \%$ of COVID-19 patients 17.5 days after ICU hospitalization. In our study, such a vitamin $C$ deficiency indicated that intakes of this antioxidant given at nutritional doses as recommended by ESPEN guidelines [34] were therefore not sufficient to maintain vitamin $C$ concentration in the reference interval, as already observed in other critically ill patients [35]. In fact, intravenous (IV) administration only has been able to restore high-level ascorbic acid plasma concentration [36]. Even if always being a matter of controversy $[37,38]$, high doses (several grams) of IV vitamin C could help reducing the "cytokines storm" [39] and could have immunosuppressive effects [40]. When compared to a placebo group, Zhang et al. [41] recently demonstrated in a preprint paper without peer-reviewing that high-doses of IV vitamin C (12 g every $12 \mathrm{~h}$ ) for 7 days improved oxygenation in COVID-19 critically ill patients. Moreover, blood interleukin-6 levels were significantly reduced after 7 days of treatment. Unfortunately, the authors did not monitor serum vitamin $C$ concentration before and after IV injection.

Glutathione, a crucial antioxidant, is well known to modulate the behavior of many cells including the cells of the immune system, augmenting the innate and the adaptive immunity as well as conferring protection against microbial, viral and parasitic infections [42,43]. Interaction between GSH metabolism and several diseases were also well described [44]. For example, low glutathione has been associated with abnormalities in the lung surfactant system, while normal levels of intracellular glutathione may exert a critical negative control on the elaboration of pro-inflammatory cytokines [45]. Our study revealed 
that the GSH status was significantly altered downwards in our COVID-19 patients, particularly in the long stayers. Recently, Polinokov [46] concluded that blood deficiency in GSH exacerbated COVID-19 illness. In two COVID-19 patients, Horowitz et al. [47] observed that the $2 \mathrm{~g}$ per os or IV glutathione improved their dyspnea within $1 \mathrm{~h}$ of use. Repeated use of $2 \mathrm{~g}$ was effective in further relieving respiratory symptoms. Recently, Poe and Corn, Rangel-Mendez et al. and De Flora et al. [48-50] hypothesized that N-acetyl-Lcysteine (NAC) as a precursor of glutathione could act as a potential therapeutic agent in the treatment of COVID-19 through a variety of potential mechanisms, including increasing glutathione, improving T cell response, and modulating inflammation. Interestingly, we also observed in parallel a deep depletion in PSH. By its large amount in plasma, albumin dotted of -SH groups represents around 75\% of the thiol pool [51]. Infectious and inflammatory states are known to alter the serum concentration of albumin [52], as observed in the present study. Nevertheless, we found no correlation between PSH and albumin.

The determination of the total antioxidant capacity (TAC) has been proposed as a global measure of non-enzymatic antioxidant efficiency despite the problem of inference with uric acid [53,54]. Using an original electrochemical methodology developed by us [31], we showed that the TAC as evaluated by the PAOT $^{\circledR}$ score was logically decreased in COVID-19 patients most probably because of their very low levels in vitamin C and GSH. Nevertheless, no correlation could be evidenced between both antioxidants and TAC as also shown in the EPIC Granada-Gipuzkoa study [55]. Nevertheless, it was interesting to note the positive correlation of PAOT ${ }^{\circledR}$ score and the Vit E/cholesterol. More investigations are required to better understand and evaluate the real role and place of TAC in the OSS.

\subsection{Trace Elements Analysis}

Adequate levels of Se are important for initiating immunity, but they are also involved in regulating excessive immune responses and chronic inflammation [56]. In the present study, selenium was close to the inferior normal value, and an important deficit was detected in the three short stayers. Moghaddam et al. [57] analyzed the selenium status in a cohort of 33 COVID-19 patients providing a set of four consecutive serum samples taken from ICU admission to ICU discharge (median: 19 (3-46) days) or death (median: 10 (2-32) days). When compared to reference data issued from a European cross-sectional analysis, these authors found, in agreement with us, a pronounced deficit with a very low selenium concentration in $43.4 \%$ of the samples, more particularly in those of short stayers (Figure S2, see Supplementary Material). By contrast, all our long stayers exhibited individual values being within the reference interval, significantly higher than those of short stayers. This could suggest that the nutritional intakes in selenium could have been adequate to compensate initial deficits.

In their paper, Moghaddam et al. [57] also analyzed glutathione peroxidase (GPx), an antioxidant enzyme requiring glutathione (GSH) and selenium as co-factors to eliminate lipid peroxides $(\mathrm{ROOH})$. Unlike the present results, these authors found a significant correlation between selenium and GPx. Even if the GPx level was elevated in all our patients, it should be surprising that its activity was optimal given the low level in its co-factor GSH but also the elevated concentration in $\mathrm{ROOH}$.

Copper exhibits, at non-physiological concentration, pro-oxidant activities by inducing free radical formation through Fenton-like reaction [58]. The potential pro-oxidant effect of copper was suggested in our study by both its strong positive correlation with $\mathrm{ROOH}$ and negative correlation with $\gamma$-tocopherol, a major antioxidant acting as lipid peroxidation inhibitor. Besides an important role in immunity [59], zinc also had antioxidant properties [60] as main co-factor of superoxide dismutase (SOD) but also as inhibitor of free radical reaction induced by copper. As shown in Figure S2 (see Supplementary Material), $\mathrm{Cu} / \mathrm{Zn}$ ratio values higher than the UNV were found in half of the patients. As part of an OS assessment, some authors suggested that the $\mathrm{Cu} / \mathrm{Zn}$ ratio should be considered as a better indicator of OS presence than copper alone $[61,62]$. Such a ratio is rarely analyzed in critically ill patients. The strong relationship between health status and $\mathrm{Cu} / \mathrm{Zn}$ ratio has, 
however, been extensively reviewed by Malavolta [63]. So, human studies have well evidenced that inflammatory stimuli modify serum concentration of $\mathrm{Cu}$ and $\mathrm{Zn}$ by increasing the former and decreasing the latter through a hepatic organized mechanism [64]. In our study, we effectively observed that the $\mathrm{Cu} / \mathrm{Zn}$ ratio was positively correlated with CRP. Moreover, the ratio also tended to be positively correlated with ROOH (Table 5). This is in agreement with previous papers reporting that increased copper/zinc ratio was correlated with heightened systemic oxidant load in aging-related degenerative diseases [65], patients undergoing renal dialysis [66] or women taking oral contraceptive [30].

\subsection{Analysis of Lipid Oxidation Biomarkers}

Even if the elevated level of lipid peroxides was not statistically different from the reference interval, a majority of COVID-19 patients (63.6\%) exhibited higher levels than the upper reference value (Figure S2, see Supplementary Material). The strong correlation observed between $\mathrm{ROOH}$ and copper highlighted the important role of this last trace element in the development of the lipid peroxidation process. By contrast, ox-LDL, as another form of lipid peroxidation [67], did not confirm the presence of increased oxidative damages to lipids. However, ox-LDL elicited the production of both IgG and IgM ox-LDL antibodies. It is accepted that IgG ox-LDL antibodies had pro-inflammatory effect while IgM were anti-atherogenic [68]. Surprisingly, we observed in our study two distinct profiles in IgG values (Figure S2, see Supplementary Material). We have no clear explanation related to such discrepancy.

\subsection{Analysis of Inflammation Biomarkers}

In COVID-19 patients as well as in critically ill patients, increased plasma inflammatory markers such as CRP have been well described [69]. In our study, we confirmed such inflammatory process (Table 4) as especially evidenced by elevated levels in MPO, an enzyme specifically localized in neutrophils. This reflects the activation of these cells probably by cytokines leading to the release in the extracellular medium of ROS in high amount [70]. MPO can also catalyze the formation of toxic hypochlorous acid ( $\mathrm{HOCl})$, able to oxidize albumin [71]. Oxidation of $-\mathrm{SH}$ groups of albumin is known to occur in pathophysiological processes associated with increased inflammation and oxidative stress [51] and potentially in COVID-19 patients [72]. This could explain why we have observed a negative correlation between MPO and albumin in our patients.

Our observational study did not allow us to conclude if increased OS and antioxidant depletion could be directly attributed to the COVID-19 disease by itself or by its complications and the delivered organ supports [73-75]. Nevertheless, significant alterations in vitamin C, GSH and selenium concentrations, all molecules playing a key role in the immunity, raise questions in the particular framework of the COVID-19 pathogenesis. Associated to increased lipid peroxidation, these observations should therefore create opportunities to explore potential approaches for prevention or treatment by antioxidants, as observed in COVID-19 patients [76-80]. As recently suggested for vitamin C and glutathione [33,47,81], monitoring of OSS should be implemented in COVID-19 critically ill patients, including vitamin $\mathrm{C}, \mathrm{GSH}$ in association with $\mathrm{PSH}$, and, finally, $\mathrm{ROOH}$ in association with the $\mathrm{Cu} / \mathrm{Zn}$ ratio and CRP.

\subsection{Study Limitations}

First, only a few number of patients have been studied and blood sampling timing was not standardized. Second, some clinical data, such as the number of septic complications, were not taken into account in the present analysis. Moreover, OSS status of our patients at ICU admission was unfortunately unknown. Our patients were overweight (median value: $29 \mathrm{~kg} / \mathrm{m}^{2}$ ) and some of them had pre-existing medical conditions such as diabetes $(64 \%)$ and / or arterial hypertension $(55 \%)$, all conditions being potentially associated with basal increased OS [82-84]. If focusing on vitamin C, the literature review indicated, however, that these pathological situations by themselves could not be responsible for 
hypovitaminosis C [85-88]. Finally, nutritional support varied between patients and their average energy and protein intakes was lower than recommended. This could have influenced the observed OS status.

\section{Conclusions}

The systemic OSS was strongly altered in critically ill COVID-19 patients as evidenced by increased lipid peroxidation but also by deficits in some antioxidants (vitamin C, glutathione, thiol proteins) and trace elements (selenium). Strong positive correlations between lipid peroxides and $\mathrm{Cu}$ and the negative correlation between $\gamma$-tocopherol and $\mathrm{Cu}$ highlighted the role played by copper in increased OS in COVID-19 patients. These observations need to be confirmed on a larger population.

Supplementary Materials: The following are available online at https:/ /www.mdpi.com/2076-392 1/10/2/257/s1, Figure S1: Individual plasma values in antioxidants observed in COVID-19 patients $(\mathrm{N}=9)$. Figure S2: Individual plasma values in trace elements and markers of lipid peroxidation observed in COVID-19 patients ( $\mathrm{N}=9$ ). Figure S3: Individual plasma or blood values in inflammatory biomarkers observed in COVID-19 patients $(\mathrm{N}=9)$., Table S1: Statistical comparison of median values for all investigated OS biomarkers between short and long stayers., Table S2: Percentage (\%) of patients among short $(\mathrm{N}=3)$ and long stayers $(\mathrm{N}=6)$ having individual values of OS biomarkers below the lower normal value (LNV) and above the upper normal value (UNV).

Author Contributions: J.P. and A.-F.R. designed and conducted the study and wrote the paper. E.C., C.C., and C.L.G. were the main investigators for the analysis of the biomarkers. E.B. and J.-P.C.-B. assumed the pre-analytical treatment of the samples. S.M. was in charge of the PAOT ${ }^{\circledR}$ score determination. A.A. and A.C. performed the statistical analysis and contributed to interpretation of data. M.F. took care of the nutritional care in COVID-19 patients. B.M. and J.-O.D., as heads respectively of Intensive Care Department and Cardiovascular Surgery Department, gave their consent for the study to be carried out. All authors have read and agreed to the published version of the manuscript.

Funding: This research received no external funding.

Institutional Review Board Statement: The study protocol was formally approved by the Ethics committee of University-CHU Liège, Belgium under national reference B707202000035, Local reference 2020-201, on 5 June 2020.

Informed Consent Statement: All legal representatives of the patients were instructed on the study objectives and signed informed consent.

Data Availability Statement: The datasets analyzed during the current study are available from the corresponding author on reasonable request.

Conflicts of Interest: The authors declare no conflict of interest.

\section{References}

1. Zhu, N.; Zhang, D.; Wang, W.; Li, X.; Yang, B.; Song, J.; Zhao, X.; Huang, B.; Shi, W.; Lu, R.; et al. A Novel Coronavirus from Patients with Pneumonia in China, 2019. N. Engl. J. Med. 2020, 382, 727-733. [CrossRef]

2. Munster, V.J.; Koopmans, M.; van Doremalen, N.; van Riel, D.; de Wit, E. A novel coronavirus emerging in China-key questions for impact assessment. N. Engl. J. Med. 2020, 382, 692-694. [CrossRef] [PubMed]

3. Coperchinia, F.; Chiovatoa, L.; Crocea, L.; Magria, F.; Rotondia, M. The cytokine storm in COVID-19: An overview of the involvement of the chemokine/chemokine-receptor system. Cytokine Growth Factor Rev. 2020, 53, 25-32. [CrossRef]

4. Castelli, V.; Cimini, A.; Ferri, C. Cytokine Storm in COVID-19: When You Come Out of the Storm, You Won't Be the Same Person Who Walked in. Front. Immunol. 2020, 11. [CrossRef] [PubMed]

5. Catanzaro, M.; Fagiani, F.; Racchi, M.; Corsini, E.; Govoni, S.; Lanni, C. Immune response in COVID-19: Addressing a pharmacological challenge by targeting pathways triggered by SARS-CoV-2. Signal Transduct. Target. Ther. 2020, 5, 1-10. [CrossRef]

6. Carsana, L.; Sonzogni, A.; Nasr, A.; Rossi, R.S.; Pellegrinelli, A.; Zerbi, P.; Rech, R.; Colombo, R.; Antinori, S.; Corbellino, M.; et al. Pulmonary post-mortem findings in a series of COVID-19 cases from northern Italy: A two-centre descriptive study. Lancet Infect. Dis. 2020, 20, 1135-1140. [CrossRef] 
7. Steven, S.; Frenis, K.; Oelze, M.; Kalinovic, S.; Kuntic, M.; Jimenez, M.T.B.; Vujacic-Mirski, K.; Helmstädter, J.; Kröller-Schön, S.; Münzel, T.; et al. Vascular Inflammation and Oxidative Stress: Major Triggers for Cardiovascular Disease. Oxidative Med. Cell. Longev. 2019, 2019, 1-26. [CrossRef]

8. Zuo, L.; Prather, E.R.; Stetskiv, M.; Garrison, D.E.; Meade, J.R.; Peace, T.I.; Zhou, T. Inflammaging and oxidative stress in human diseases: From molecular mechanisms to novel treatments. Int. J. Mol. Sci. 2019, 20, 4472. [CrossRef]

9. Guerrero, C.A.; Acosta, O. Inflammatory and oxidative stress in rotavirus infection. World J. Virol. 2016, 5, 38-62. [CrossRef]

10. Jones. D.P. Redefining oxidative stress. Antioxid. Redox Signal 2006, 8, 1865-1879.

11. Ito, F.; Sono, Y.; Ito, T. Measurement and Clinical Significance of Lipid Peroxidation as a Biomarker of Oxidative Stress: Oxidative Stress in Diabetes, Atherosclerosis, and Chronic Inflammation. Antioxidants 2019, 8, 72. [CrossRef] [PubMed]

12. Cecchini, R.; Cecchini, A.L. SARS-CoV-2 infection pathogenesis is related to oxidative stress as a response to aggression. Med Hypotheses 2020, 143, 110102. [CrossRef]

13. Zhang, H.; Penninger, J.M.; Li, Y.; Zhong, N.; Slutsky, A.S. Angiotensin-converting enzyme 2 (ACE2) as a SARS-CoV-2 receptor: Molecular mechanisms and potential therapeutic target. Intensive Care Med. 2020, 46, 586-590. [CrossRef]

14. Brojakowska, A.; Jagat Narula, B.A.; Shimony, R.; Bander, J. Clinical implications of SARS-CoV-2 interaction with renin angiotensin system JACC review topic of the week. J. Am. Coll. Cardiol. 2020, 75, 3085-3095. [CrossRef] [PubMed]

15. Rabelo, L.A.; Alenina, N.; Bader, M. ACE2-angiotensin-(1-7)-Mas axis and oxidative stress in cardiovascular disease. Hypertens. Res. 2011, 34, 154-160. [CrossRef] [PubMed]

16. Wen, H.; Gwathmey, J.K.; Xie, L.-H. Oxidative stress-mediated effects of angiotensin II in the cardiovascular system. World J. Hypertens. 2012, 2, 34-44. [CrossRef] [PubMed]

17. Lippi, G.; Mattiuzzi, C. Hemoglobin value may be decreased in patients with severe coronavirus disease 2019. Hematol. Transfus. Cell Ther. 2020, 42, 116-117. [CrossRef]

18. Vasoncellos, I.R.C.; Dutra, F.F.; Siqueira, M.S.; Paula-Neto, H.A.; Dahan, J.; Kiarely, E.; Carneiro, L.A.M.; Bozza, M.T.; Travassos, L.H. Protein aggregation as a cellular response to oxidative stress induced by heme and iron. Proc. Natl. Acad. Sci. USA 2016, 113, 7474-7482.

19. Cavezzi, A.; Troiani, E.; Corrao, S. COVID-19: Hemoglobin, iron, and hypoxia beyond inflammation. A narrative review. Clin. Pr. 2020, 10, 1271. [CrossRef]

20. Vallelian, F.; Schaer, C.A.; Deuel, J.W.; Ingoglia, G.; Humar, R.; Buehler, P.W.; Schaer, D.J. Revisiting the putative role of heme as a trigger of inflammation. Pharmacol. Res. Perspect. 2018, 6, e00392. [CrossRef]

21. Sultan, S.; Sultan, M. COVID-19 cytokine storm and novel truth. Med. Hypotheses 2020, 144, 109875. [CrossRef]

22. Huertas, A.; Montani, D.; Savale, L.; Pichon, J.; Tu, L.; Parent, F.; Guignabert, C.; Humbert, M. Endothelial cell dysfunction: A major player in SARS-CoV-2 infection (COVID-19)? Eur. Respir. J. 2020, 56, 2001634. [CrossRef]

23. Froldi, G.; Dorigo, P. Endothelial dysfunction in Coronavirus disease 2019 (COVID-19): Gender and age influences. Med Hypotheses 2020, 144, 110015. [CrossRef]

24. Heiss, C.; Rodriguez-Mateos, A.; Kelm, M. Central Role of eNOS in the Maintenance of Endothelial Homeostasis. Antioxidants Redox Signal 2015, 22, 1230-1242. [CrossRef] [PubMed]

25. Schulz, E.; Gori, T.; Münzel, T. Oxidative stress and endothelial dysfunction in hypertension. Hypertens. Res. 2011, 34, 665-673. [CrossRef] [PubMed]

26. Scioli, M.G.; Storti, G.; D'Amico, F.; Guzmán, R.R.; Centofanti, F.; Doldo, E.; Miranda, E.M.C.; Orlandi, A. Oxidative Stress and New Pathogenetic Mechanisms in Endothelial Dysfunction: Potential Diagnostic Biomarkers and Therapeutic Targets. J. Clin. Med. 2020, 9, 1995. [CrossRef] [PubMed]

27. Delgado-Roche, L.; Mesta, F. Oxidative stress as key player in severe acute respiratory syndrome coronaivirus (SARS-COV) infection. Arch. Med. Res. 2020, 51, 384-387. [CrossRef] [PubMed]

28. Derouiche, S. Oxidative stress associated SARS-CoV-2 (COVID-19) increases the severity of lung disease-A systematic review. Infect. Dis. Epidemiol. 2020. [CrossRef]

29. Pincemail, J.; Defraigne, J.; Cheramy-Bien, J.; Dardenne, N.; Donneau, A.; Albert, A.; Labropoulos, N.; Sakalihasan, N. On the potential increase of the oxidative stress status in patients with abdominal aortic aneurysm. Redox Rep. 2012, 17, 139-144. [CrossRef]

30. Pincemail, J.; Vanbelle, S.; Gaspard, U.; Collette, G.; Haleng, J.; Cheramy-Bien, J.; Charlier, C.; Chapelle, J.; Giet, D.; Albert, A.; et al. Effect of different contraceptive methods on the oxidative stress status in women aged 40-48 years from the ELAN study in the province of Liège, Belgium. Hum. Reprod. 2007, 22, 2335-2343. [CrossRef]

31. Joël, P.; Mouna-Messaouda, K.; Jean-Paul, C.-B.; Jean-Olivier, D.; Smail, M. Electrochemical Methodology for Evaluating Skin Oxidative Stress Status (SOSS). Diseases 2019, 7, 40. [CrossRef]

32. Lindblad, M.; Tveden-Nyborg, P.; Lykkesfeldt, J. Regulation of Vitamin C Homeostasis during Deficiency. Nutrients 2013, 5, 2860-2879. [CrossRef]

33. Chiscano-Carnon, L.; Ruiz-Rodriguez, J.C.; Rulz-Sanmartin, A.; Roca, O.; Ferrer, R. Vitamin C levels in patients with SARS-CoV-2associated acute respiratory distress syndrome. Crit. Care 2020, 24, 1-3. [CrossRef]

34. Singer, P.; Blaser, A.R.; Berger, M.M.; Alhazzani, W.; Calder, P.C.; Casaer, M.P.; Hiesmayr, M.; Mayer, K.; Montejo, J.C.; Pichard, C.; et al. ESPEN guideline on clinical nutrition in the intensive care unit. Clin. Nutr. 2019, 38, 48-79. [CrossRef] [PubMed]

35. Carr, A.C.; Rosengrave, P.C.; Bayer, S.; Chambers, S.; Mehrtens, J.; Shaw, G.M. Hypovitaminosis C and vitamin C deficiency in critically ill patients despite recommended enteral and parenteral intakes. Crit. Care 2017. [CrossRef] 
36. Padayatty, S.J.; Sun, H.; Wang, Y.; Riordan, H.D.; Hewitt, S.M.; Katz, A.; Wesley, R.A.; Levine, M. Vitamin C Pharmacokinetics: Implications for Oral and Intravenous Use. Ann. Intern. Med. 2004, 140, 533-537. [CrossRef]

37. Nabzdyk, C.S.; Bittner, E.A. Vitamin C in the critically ill-Indications and controversies. World J. Crit. Care Med. 2018, 7, 52-61. [CrossRef] [PubMed]

38. Hemilä, H.; Chalker, E. Vitamin C Can Shorten the Length of Stay in the ICU: A Meta-Analysis. Nutrients 2019, 11, 708. [CrossRef] [PubMed]

39. Boretti, A.; Banik, B.K. Intravenous vitamin C for reduction of cytokines storm in acute respiratory distress syndrome. PharmaNutrition 2020, 12, 100190. [CrossRef]

40. Erol, A. High-dose Intravenous Vitamin C Treatment for COVID-19. OSF Preprints 2020. [CrossRef]

41. Zhang, J.; Rao, X.; Li, Y.; Zhu, Y.; Liu, F.; Guo, G.; Luo, G.; Meng, Z.; De Backer, D.; Xiang, H.; et al. High-dose vitamin C infusion for the treatment of critically ill COVID-19. Ann. Intens. Care 2020. on press.

42. Dröge, W.; Breitkreutz, R. Glutathione and immune function. Proc. Nutr. Soc. 2000, 59, 595-600. [CrossRef]

43. Morris, D.; Khurasany, M.; Nguyen, T.; Kim, J.; Guilford, F.; Mehta, R.; Gray, D.; Saviola, B.; Venketaraman, V. Glutathione and infection. Biochim. et Biophys. Acta (BBA) Gen. Subj. 2013, 1830, 3329-3349. [CrossRef]

44. Townsend, D.; Tewa, K.D.; Tapierob, H. The importance of glutathione in human disease. Biomed Pharm. 2003, 57, 145-155. [CrossRef]

45. Morris, P.E.; Bernard, G.R.; Bernard, C.R. Significance of Glutathione in Lung Disease and Implications for Therapy. Am. J. Med Sci. 1994, 307, 119-127. [CrossRef]

46. Polonikov, A. Endogenous Deficiency of Glutathione as the Most Likely Cause of Serious Manifestations and Death in COVID-19 Patients. ACS Infect. Dis. 2020, 6, 1558-1562. [CrossRef] [PubMed]

47. Horowitz, R.I.; Freeman, P.R.; Bruzzese, J. Efficacy of glutathione therapy in relieving dyspnea associated with COVID-19 pneumonia: A report of 2 cases. Respir. Med. Case Rep. 2020, 30, 101063. [CrossRef]

48. Poe, F.L.; Corn, J. N-Acetylcysteine: A potential therapeutic agent for SARS-CoV-2. Med. Hypotheses 2020, 143, 109862. [CrossRef]

49. Jorge-Aarón, R.-M.; Moo-Puc, R.E. N-acetylcysteine as a potential treatment for COVID-19. Futur. Microbiol. 2020, 15, 959-962. [CrossRef]

50. De Flora, S.; Balansky, R.; La Maestra, S. Rationale for the use of N -acetylcysteine in both prevention and adjuvant therapy of COVID-19. FASEB J. 2020, 34, 13185-13193. [CrossRef] [PubMed]

51. Turell, L.; Radi, R.; Alvarez, B. The thiol pool in human plasma: The central contribution of albumin to redox processes. Free. Radic. Biol. Med. 2013, 65, 244-253. [CrossRef]

52. Bharadwaj, S.; Ginoya, S.; Tandon, P.; Gohel, T.D.; Guirguis, J.; Vallabh, H.; Jevenn, A.; Hanouneh, I. Malnutrition vs nutritional assessment. Gastroenterol Rep. 2016, 4, 272-280.

53. Serafini, M.; Del Rio, D. Understanding the association between dietary antioxidants, redox status and disease: Is the Total Antioxidant Capacity the right tool? Redox Rep. 2004, 9, 145-152. [CrossRef]

54. Bartosz, G. Non-enzymatic antioxidant capacity assays: Limitations of use in biomedicine. Free. Radic. Res. 2010, 44, 711-720. [CrossRef] [PubMed]

55. Carrión-García, C.J.; Guerra-Hernández, E.J.; García-Villanova, B.; Serafini, M.; Sánchez, M.-J.; Amiano, P.; Molina-Montes, E. Plasma Non-Enzymatic Antioxidant Capacity (NEAC) in Relation to Dietary NEAC, Nutrient Antioxidants and InflammationRelated Biomarkers. Antioxidants 2020, 9, 301. [CrossRef] [PubMed]

56. Huang, Z.; Rose, A.H.; Hoffmann, P.R. The Role of Selenium in Inflammation and Immunity: From Molecular Mechanisms to Therapeutic Opportunities. Antioxid. Redox Signal 2012, 16, 705-743. [CrossRef] [PubMed]

57. Moghaddam, A.; Heller, R.A.; Sun, Q.; Seelig, J.; Cherkezov, A.; Seibert, L.; Hackler, J.; Seemann, P.; Diegmann, J.; Pilz, M.; et al. Selenium Deficiency Is Associated with Mortality Risk from COVID-19. Nutrients 2020, 12, 2098. [CrossRef] [PubMed]

58. Gaetke, L.M.; Chow, C.K. Copper toxicity, oxidative stress and antioxidant nutrients. Toxicology 2003, 189, 147-163. [CrossRef]

59. Prasad, A.S. Zinc in Human Health: Effect of Zinc on Immune Cells. Mol. Med. 2008, 14, 353-357. [CrossRef]

60. Jarosz, M.; Olbert, M.; Wyszogrodzka, G.; Młyniec, K.; Librowski, T. Antioxidant and anti-inflammatory effects of zinc. Zincdependent NF- $\mathrm{KB}$ signaling. Inflammopharmacology 2017, 25, 11-24. [CrossRef] [PubMed]

61. Guo, C.-H.; Chen, P.-C.; Yeh, M.-S.; Hsiung, D.-Y.; Wang, C.-L. Cu/Zn ratios are associated with nutritional status, oxidative stress, inflammation, and immune abnormalities in patients on peritoneal dialysis. Clin. Biochem. 2011, 44, 275-280. [CrossRef]

62. Ozturk, P.; Kurutas, E.B.; Ataseven, A. Copper/zinc and copper/selenium ratios, and oxidative stress as biochemical markers in recurrent aphthous stomatitis. J. Trace Elements Med. Biol. 2013, 27, 312-316. [CrossRef] [PubMed]

63. Malavolta, M.; Piacenza, F.; Basso, A.; Giacconi, R.; Costarelli, L.; Mocchegiani, E. Serum copper to zinc ratio: Relationship with aging and health status. Mech. Ageing Dev. 2015, 151, 93-100. [CrossRef] [PubMed]

64. Milanino, R.; Marrella, M.; Gasperini, R.; Pasqualicchio, M.; Velo, G. Copper and zinc body levels in inflammation: An overview of the data obtained from animal and human studies. Inflamm. Res. 1993, 39, 195-209. [CrossRef]

65. Mezzetti, A.; Pierdomenico, S.D.; Costantini, F.; Romano, F.; De Cesare, D.; Cuccurullo, F.; Imbastaro, T.; Riario-Sforza, G.; Di Giacomo, F.; Zuliani, G.; et al. Copper/zinc ratio and systemic oxidant load: Effect of aging and aging-related degenerative diseases. Free. Radic. Biol. Med. 1998, 25, 676-681. [CrossRef]

66. Guo, C.-H.; Wang, C.-L. Effects of Zinc Supplementation on Plasma Copper/Zinc Ratios, Oxidative Stress, and Immunological Status in Hemodialysis Patients. Int. J. Med. Sci. 2013, 10, 79-89. [CrossRef] 
67. Shen, Y.; Yang, T.; Guo, S.; Li, X.; Chen, L.; Wang, T.; Wen, F.-Q. Increased Serum ox-LDL Levels Correlated with Lung Function, Inflammation, and Oxidative Stress in COPD. Mediat. Inflamm. 2013, 2013, 1-5. [CrossRef]

68. Hulthe, J. Antibodies to oxidized LDL in atherosclerosis development-clinical and animal studies. Clin. Chim. Acta 2004, 348, 1-8. [CrossRef]

69. Gozalbo-Rovira, R.; Gimenez, E.; Latorre, V.; Francés-Gómez, C.; Albert, E.; Buesa, J.; Marina, A.; Blasco, M.L.; Signes-Costa, J.; Rodríguez-Díaz, J.; et al. SARS-CoV-2 antibodies, serum inflammatory biomarkers and clinical severity of hospitalized COVID-19 patients. J. Clin. Virol. 2020, 131, 104611. [CrossRef] [PubMed]

70. Loria, V.; Dato, I.; Graziani, F.; Biasucci, L.M. Myeloperoxidase: A New Biomarker of Inflammation in Ischemic Heart Disease and Acute Coronary Syndromes. Mediat. Inflamm. 2008, 2008, 1-4. [CrossRef]

71. Vlasova, I.I.; Sokolov, A.V.; Kostevich, V.A.; Mikhalchik, E.V.; Vasilyev, V.B. Myeloperoxidase-Induced Oxidation of Albumin and Ceruloplasmin: Role of Tyrosines. Biochemestry (Moscow) 2019, 84, 652-662. [CrossRef] [PubMed]

72. Rahmani-Kukia, N.; Abbasi, A.; Pakravan, N.; Hassan, Z.M. Measurement of oxidized albumin: An opportunity for diagnoses or treatment of COVID-19. Bioorganic Chem. 2020, 105, 104429. [CrossRef]

73. Schorah, C.J.; Downing, C.; Piripitsi, A.; Gallivan, L.; Al-Hazaa, A.H.; Sanderson, M.J.; Bodenham, A. Total vitamin C, ascorbic acid, and dehydroascorbic acid concentrations in plasma of critically ill patients. Am. J. Clin. Nutr. 1996, 63, 760-765. [CrossRef]

74. Metnitz, P.G.H.; Bartens, C.; Fischer, M.; Fridrich, P.; Steltzer, H.; Druml, W. Antioxidant status in patients with acute respiratory distress syndrome. Intensiv. Care Med. 1999, 25, 180-185. [CrossRef]

75. Ruocco, M.A.C.; Cechinatti, E.D.P.; Barbosa, F.; Navarro, A.M. Zinc and selenium status in critically ill patients according to severity stratification. Nutrients 2018, 45, 85-89. [CrossRef]

76. Zhang, J.; Xie, B.; Hashimoto, K. Current status of potential therapeutic candidates for the COVID-19 crisis. Brain Behav. Immun. 2020, 87, 59-73. [CrossRef]

77. Carr, A.C. Micronutrient status of COVID-19 patients: A critical consideration. Crit. Care 2020, 24, 349. [CrossRef]

78. Jing-Zhang, W.; Rui-Ying, Z.; Bai, J. An anti-oxidative therapy for ameliorating cardiac injuries of critically ill COVID-19-infected patients. Int. J. Cardiol. 2020, 312, 137-138.

79. Loffredo, L.; Violi, F. COVID-19 and cardiovascular injury: A role for oxidative stress and antioxidant treatment? Int. J. Cardiol. 2020, 312, 136. [CrossRef]

80. Kassi, E.N.; Papavassiliou, K.A.; Papavassiliou, A.G. Defective Anti-oxidant System: An Aggravating Factor for COVID-19 Patients Outcome? Arch. Med Res. 2020, 51, 726-727. [CrossRef] [PubMed]

81. Zhang, L.; Liu, Y. Potential interventions for novel coronavirus in China: A systematic review. J. Med Virol. 2020, 92, 479-490. [CrossRef] [PubMed]

82. Marseglia, L.; Manti, S.; D'Angelo, G.; Nicotera, A.; Parisi, E.; Di Rosa, G.; Gitto, E.; Arrigo, T. Oxidative Stress in Obesity: A Critical Component in Human Diseases. Int. J. Mol. Sci. 2014, 16, 378-400. [CrossRef] [PubMed]

83. Oguntibeju, O.O. Type 2 diabetes mellitus, oxidative stress and inflammation: Examining the links. Int. J. Physiol. Pathophysiol. Pharmacology 2019, 11, 45-63.

84. González, J.; Valls, N.; Brito, R.; Rodrigo, R. Essential hypertension and oxidative stress: New insights. World J. Cardiol. 2014, 6, 353-366. [CrossRef]

85. Canoy, D.; Wareham, N.; Welch, A.; Bingham, S.; Luben, R.; Day, N.; Khaw, K.-T. Plasma ascorbic acid concentrations and fat distribution in 19068 British men and women in the European Prospective Investigation into Cancer and Nutrition Norfolk cohort study. Am. J. Clin. Nutr. 2005, 82, 1203-1209. [CrossRef]

86. Sinclair, A.; Taylor, P.; Lunec, J.; Girling, A.; Barnett, A. Low Plasma Ascorbate Levels in Patients with Type 2 Diabetes Mellitus Consuming Adequate Dietary Vitamin C. Diabet. Med. 1994, 11, 893-898. [CrossRef]

87. Wilson, R.; Willis, J.; Gearry, R.; Skidmore, P.; Fleming, E.; Frampton, C.; Carr, A. Inadequate Vitamin C Status in Prediabetes and Type 2 Diabetes Mellitus: Associations with Glycaemic Control, Obesity, and Smoking. Nutrients 2017, 9, 997. [CrossRef]

88. Kurl, S.; Tuomainen, T.; Laukkanen, J.A.; Nyyssonen, K.; Lakka, T.; Sivenius, J.; Salonen, J. Plasma Vitamin C Modifies the Association Between Hypertension and Risk of Stroke. Stroke 2002, 33, 1568-1573. [CrossRef] [PubMed] 